\title{
Diagnosis of Bacterial Vaginosis among Symptomatic Egyptian Women: Value of Assessing Bacterial Sialidase Activity
}

\author{
Fatma AL-Zahraa M. Gomaa ${ }^{1}$, Hala M. Hafez ${ }^{2}$, Ahmed Al Anwar ${ }^{3}$ and \\ Noureen I. El-Metwally ${ }^{1}$
}
${ }^{1}$ Microbiology and Immunology Department, Faculty of Pharmacy, Al-Azhar University, Egypt
${ }^{2}$ Clinical Pathology Department, Faculty of Medicine, Ain Shams University, Egypt
${ }^{3}$ Gynaecology and Obstetrics Department, Faculty of Medicine, Ain Shams University, Egypt
*Corresponding author

\begin{tabular}{|c|c|}
\hline & A B S T R A C T \\
\hline & The development of point-of-care tests that are accurate, simple, rapid, low cost, and that \\
\hline Keywords & do not require high levels of training for their interpretation is integral to improving the \\
\hline $\begin{array}{l}\text { Vaginosis, } \\
\text { BV, }\end{array}$ & The present study aimed at evaluating the usefulness of assessing the bacterial sialidase \\
\hline $\begin{array}{l}\text { Sialidase, } \\
\text { BVBlue, Nugent. }\end{array}$ & methods for diagnosis of bacterial vaginosis (BV). The study included 50 female patients \\
\hline Article Info & \\
\hline $\begin{array}{l}\text { Accepted: } \\
06 \text { March } 2017 \\
\text { Available Online: } \\
10 \text { April } 2017\end{array}$ & $\begin{array}{l}\text { activity. BV was detected in } 18 \% \text { of the studied women by all of the diagnostic methods. } \\
\text { Compared to Nugent's score } \geq 7 \text {, the detection of sialidase by BVBlue test had } 100 \% \\
\text { sensitivity and } 84.6 \% \text { specificity. There was a good agreement between the results of } \\
\text { BVBlue test and clinical diagnosis using Amsel's criteria. We concluded that the }\end{array}$ \\
\hline & $\begin{array}{l}\text { determination of sialidase activity by BVBlue test can be a simple, rapid, and sensitive } \\
\text { alternative to routine diagnostic methods that require expert manpower and sophisticated } \\
\text { techniques. }\end{array}$ \\
\hline
\end{tabular}

\section{Introduction}

Bacterial vaginosis (BV) is the most common lower genital tract infection affecting millions of sexually-active women annually (Jones et al., 2007). It is a polymicrobial syndrome characterized by a shift of the vaginal flora from the dominant Lactobacillus species to acquisition of diverse Gram-negative and variable anaerobic and facultative bacteria (Fredricks et al., 2005; Livengood, 2009; Rubins, 2011). Bacterial vaginosis is strongly associated with serious pregnancy-related outcomes including chorioamnionitis, spontaneous abortion, preterm labor (DiVico et al., 2011; Das et al., 2011; Jayakrishnan et al., 2016), pelvic inflammatory disease (Taylor et al., 2013), postpartum and postabortal endometritis (Haggerty et al., 2004). Moreover, it has been found to be associated with increased susceptibility to sexually-transmitted infections, such as Neisseria gonorrhoeae, Trichomonas vaginalis, Chlamydia trachomatis, Candida 
spp., and even human immunodeficiency virus (Martin et al., 1999; Bhalla et al., 2007; Allsworth and Peipert, 2011).

The complex polymicrobial nature of $\mathrm{BV}$ made its diagnosis problematic with vaginal cultures, used in the past as the primary laboratory test, found to be of little value. Organisms classically incriminated in BV (e.g., Gardenerella vaginalis) are also recovered in $36 \%$ to $55 \%$ of asymptomatic women without clinical features (Money, 2005).

Clinical diagnosis requires the presence of at least three of the following criteria (Amsel's criteria): (i) a vaginal $\mathrm{pH}$ greater than 4.5 , (ii) a homogenous thin gray-white vaginal discharge, (iii) the presence of bacteria-coated epithelial cells (clue cells) in wet mount preparations of vaginal fluid, or (iv) the release of an amine (fishy) odor after addition of $10 \% \mathrm{KOH}$ to the vaginal discharge (Tanuja et al., 2008). Although it has $90 \%$ sensitivity, diagnosis based upon clinical signs without laboratory testing has only $77 \%$ specificity (Landers et al., 2004).

Therefore, characterization of the vaginal flora by enumeration of bacterial morphotypes after Gram staining of a vaginal smear (i.e., Nugent scoring) is considered the standard method for BV diagnosis in research studies (Nugent et al., 1991). Yet, despite being highly accurate, the interpretation is subjective and the technique requires specialized training, and microscopic evaluation is not widely available for clinicians to assist in the diagnosis of $\mathrm{BV}$ (Hilbert et al., 2016).

The sheer prevalence of BV and its associated morbidities justify the exploration and development of improved diagnostic strategies that can be easily incorporated into diverse clinical settings. Many alternative diagnostic modalities focusing upon the detection of microbial virulence factors produced by the various BV-associated organisms have been proposed in the past years (Randis et al., 2009). These include detection of bacterial amines (West et al., 2003), measurement of proline aminopeptidase activity (Calderon et al., 1997) and determination of bacterial sialidase activity (Briselden et al., 1992).

Sialidases are enzymes that play a role in bacterial nutrition, cellular interactions, and immune response evasion (Cauci et al., 1998). Sialidases improve the ability of bacteria to adhere to epithelia, also has mucinase activity, which may facilitate invasion and destruction of the upper genital tract by BVassociated flora (Briselden et al., 1992; Wiggins et al., 2001). Sialidases are secreted from anaerobic Gram-negative bacterial rods such as Bacteroides, Gardnerella, and Prevotella species (Howe et al., 1999; Wiggins et al., 2001; Olmsted et al., 2003). Elevated bacterial sialidase activity has been significantly associated with BV (Wiggins et al., 2000; Myziuk et al., 2003; Akhter et al., 2010; Kampan et al., 2011) and with preterm birth in women with BV (Cauci et al., 2002).

The present study aimed at evaluating the usefulness of assessing the bacterial sialidase activity in diagnosing bacterial vaginosis by comparing its performance to that of the Nugent's scoring and Amsel's criteria being the routine methods used in our laboratories.

\section{Patients and Methods}

The study was done at the Microbiology Laboratory, Faculty of Pharmacy, Al-Azhar University and the Microbiology Laboratory, Faculty of Medicine, Ain Shams University. A total of 200 vaginal swabs was collected from 50 female patients (4 swabs/patient) suffering from excessive and/or abnormal 
vaginal discharge and attending the Outpatient Gynaecology and Obstetrics Clinics of Ain Shams University and the Matareya Teaching hospitals over the period between December 2014 and May 2016. Postmenopausal women, women who had used a lubricant or a topical vaginal medication and women engaged in a sexual relation $72 \mathrm{hrs}$ prior to sampling were excluded from the study.

\section{Ethical Approval}

The study was approved by the Committee of Ethics of Scientific Research, Faculty of Medicine, Ain Shams University and an informed consent was signed by participating women.

\section{Collection of vaginal discharge}

A sterile, non-lubricated speculum was gently inserted into the vagina during pelvic examination by a qualified clinician. Vaginal discharge was collected from the posterior vaginal fornix using sterile cotton swabs. Four swabs were collected for each patient. Swabs were labeled with the patient data and transported immediately (within 2 hours) to the Microbiology Laboratory for further processing. The swab submitted for anaerobic culture was inoculated into a tube of thioglycolate broth immediately after being collected.

Vaginal $\mathrm{pH}$ was measured, at bed side, by holding a $\mathrm{pH}$ strip against the speculum after finishing the examination and comparing the color to a $\mathrm{pH}$ chart provided by the manufacturer.

\section{Processing of vaginal swabs}

\section{Culture}

The tube containing the inoculated thioglycolate broth was incubated at $36 \pm 1^{\circ} \mathrm{C}$ overnight. Then, the swab was subcultured onto two Columbia blood agar plates and one MacConkey agar plate. One Columbia blood agar plate was incubated at $36 \pm 1^{\circ} \mathrm{C}$ under anaerobic conditions in an anaerobic jar and was examined for evidence of growth once after $72 \mathrm{hrs}$ incubation. The remaining plates were incubated at $36 \pm 1^{\circ} \mathrm{C}$ under aerobic conditions and were examined daily for evidence of growth for 72 hrs. Growing isolates were identified by their culture characteristics, morphology in Gram stain and biochemically using the Vitek 2 Compact (bioMérieux Inc.).

\section{Examination using Amsel's criteria}

The vaginal discharge was examined macroscopically and comments regarding its color, consistency, odor, and $\mathrm{pH}$ were recorded. Two drops of saline were then added onto two clean glass slides and one swab was gently pressed and rolled in a circular motion several times in the saline drops. Saline preparations were then examined as follows:

Amine test: A drop of $10 \%$ potassium hydroxide $(\mathrm{KOH})$ was added to one saline preparation and at once whiffed for the liberation of amine (fishy) odor indicative of the presence of volatile amines such as trimethylamine. The whiff test result was recorded as either positive or negative.

Examination of wet preparation: A cover slide was put on the second drop and the saline preparation was examined using the high power (40x) of the microscope for the presence of pus cells, Clue cells (epithelial cells with hazy borders due to the presence of bacteria) and budding yeasts.

The presence of at least 3 of the following criteria was considered consistent with the diagnosis of $\mathrm{BV}$ : (i) vaginal $\mathrm{pH} \geq 4.5$, (ii) homogenous, milky vaginal discharge, (iii) 
positive amine test; (iv) presence of clue cells in wet preparation.

Assessment of sialidase activity using the BVBlue $^{\circledR}$ test kit (Gryphus Diagnostics, LLC, USA):

The BVBlue test is an enzyme activity test used to detect sialidase activity in vaginal fluid specimens using a chromogenic substrate.

One cotton swab was inserted into the BV Test Vessel and the mixture was gently mixed by swirling. The BV Test Vessel containing the swab was left to stand for 10 minutes at room temperature $\left(20-24^{\circ} \mathrm{C}\right)$. Then, two drops of the Developer Solution were added to the BV Test Vessel containing the swab and gently mixed by swirling.

The appearance of a blue or green color indicates the presence of high levels of sialidase denoting a positive test for BV whereas the appearance of a yellow color indicates absence or low levels of sialidase denoting a negative test for $\mathrm{BV}$. If the test fails to provide a blue, green, or yellow color result, the test was considered invalid and was repeated.

\section{Examination of a Gram-stained smear using the Nugent's scoring system}

One cotton swab was used to prepare a vaginal smear by gently pressing and rolling it along the middle portion of a clean glass slide then leaving it to air dry. The slide was then heatfixed and stained with Gram stain. Slides were left to air dry and were then examined using the oil immersion (100X) objective and scanned for the presence of pus cells, bacteria, clue cells, budding yeasts and hyphae. At least 10 representative oil immersion fields were examined and the average number of Lactobacilli, Gardenerella vaginalis, and curved Gram-negative bacilli/oil immersion field was calculated. The number of each bacterial morphotype was scored separately and the total score was then calculated as described by Nugent et al., (1991).

\section{Interpretation}

Nugent's score between 1 and 3 was considered normal.

Nugent's score between 4 and 6 was considered intermediate.

Nugent's score $\geq 7$ denotes a smear consistent with BV.

\section{Statistical Analysis}

Statistical analysis of the data was performed using the SPSS 15 software package under Windows 7® operating system.

\section{Descriptive statistics}

Categorical data are presented in the form of number and percent (\%) whereas the continuous data are described by the mean as a measure of central tendency and by the standard deviation (SD) as a measure of variance.

\section{Analytical statistics}

The Chi-square and the Fisher-exact tests were used to determine the association between categorical parameters. A $P$ value of $\geq 0.05$ was considered non-significant whereas a $P$ value of $<0.05$ was considered significant.

The results of the BVBlue test, the Amsel's criteria and vaginal swab culture were compared to the results of the Nugent's scoring being the standard method. Accordingly their diagnostic performance was calculated and expressed as the sensitivity, specificity, positive predictive value (PPV), 
negative predictive value (NPV) and diagnostic accuracy (DA).

Agreement between the different studied test methods was measured by the kappa coefficient. The value of kappa was interpreted as follows: Kappa $<0.2=$ poor agreement; Kappa $(0.21-0.4)=$ fair agreement; Kappa $(0.41-0.6)=$ moderate agreement; Kappa (0.61-0.8) = good agreement; kappa (0.81-0.99) = excellent agreement.

\section{Results and Discussion}

\section{Demographic data of the studied patients}

The study included 50 females attending the Outpatient Gynaecology and Obstetrics Clinics at Ain Shams University and the Matareya Teaching hospitals. Their age ranged between 16 and 55 years (mean $35.1 \pm 10.4 \mathrm{SD})$. Thirty two $(32 / 50 ; 64 \%)$ of the patients were pregnant. Of the 50 studied patients, 13 (26\%) complained from a foul smelling vaginal discharge whereas 37 (74\%) complained from excessive abnormal discharge. Twelve patients (24\%) were using vaginal douches and $58 \%$ reported previous use of intra-uterine device during the previous 2 years whereas $30 \%$ were using oral contraceptives.

\section{Prevalence of BV among the studied} patients

In the present work, 18\% (9/50) of the studied women, presenting with excessive and/or malodorous vaginal discharge, gave positive results with all of the used diagnostic methods and hence were considered as BV cases. The prevalence of $\mathrm{BV}$ varied considerably (5 to $30 \%$ ) among different studies (Bradshaw et al., 2005). Our observed prevalence was similar to those reported by Madhivanan et al., (2008), Akhter et al., (2010) and Mengistie et al., (2013) in India (19.1\%),
Bangladish (21\%), and Ethiopia (19.4\%), respectively. However, lower prevalence of BV was reported in France $(7.1 \%)$ (Desseauve et al., 2012), Turkey (7.76\%) (Haltas et al., 2012) and Pakistan (10.8\%) (Taj et al., 2014). On the other hand, in the studies done in Upper Egypt, higher BV prevalence rates were reported $33.3 \%$ and 33\%) by Darwish et al., (2005) and Gad et al., (2014), respectively. Also, Tanuja et al., (2008) reported a higher BV prevalence rate in the urban areas (30\%) compared to the rural areas $(26 \%)$ of Surat. Higher rates, reaching more than 50\%, were also reported in Pakistan (Nelofer et al., 2006) and India (Khatoon et al., 2013). This considerable variation in the prevalence of $\mathrm{BV}$ among the different studies may be attributed to the difference in the study population, their sexual and hygienic habits as well as to the different diagnostic methods used.

\section{Diagnostic Performance of the BVBlue test compared to Nugent's score $\geq 7$}

Using the Nugent's scoring system, 22\% $(11 / 50)$ of the studied women, in the current work, were found to have a score $\geq 7$ consistent with the diagnosis of BV. An intermediate score was recorded in 16\% $(8 / 50)$ whereas $62 \%(31 / 50)$ had a normal score.

Using the BVBlue test, 17 out of the 50 studied women $(34 \%)$ gave positive results denoting BV whereas 33 patients $(66 \%)$ had negative results. Out of the 17 BVBlue positive patients, $11(64.7 \%)$ had a Nugent's score $\geq 7$ and were considered as true BV cases. Accordingly, the sensitivity of the BVBlue test, in the current work, was found to be $100 \%$ and the specificity was $84.6 \%$. The PPV was $64.7 \%$ whereas the NPV was $100 \%$ and the DA was $88 \%$ (Table 1). In accordance to our results, Akhter et al., (2010) and Kampan et al., (2011) reported that the BVBlue test had 100\% sensitivity and 
$100 \%$ NPV compared to the Nugent method. Yet, unlike our results, the authors reported higher specificity (98.3\%) and PPV (94.4\%) for the BVBlue test.

Variable performance characteristics were reported in the studies that evaluated the BVBlue test and compared it to the results of the Nugent's score. The previously reported sensitivity for the BVBlue test ranged from $88 \%$ to $95.3 \%$ with a specificity ranging from 92.1\% to $98.5 \%$ (Bradshaw et al., 2005; Khatoon et al., 2013, Gad et al., 2014).

In the current study, a good agreement was observed between the results of the BVBlue test and the Nugent's scoring (Kappa $=0.708)$ (Table 2). Similar results were reported by Gad et al., (2014). Excellent agreement between both tests was reported by Myziuk et al., (2003) and Kapman et al., (2010).

Diagnostic Performance of the Amsel's criteria compared to Nugent's score $\geq 7$

In the present study, 26\% (13/50) of the evaluated female patients had at least 3 of the required Amsel's criteria and hence were diagnosed as BV. Nine patients $(9 / 13 ; 69.2 \%)$ had a Nugent's score $\geq 7$ and were considered the true BV cases. Accordingly, clinical diagnosis of BV, based on Amsel's criteria, was found to have $81.8 \%$ sensitivity, $89.7 \%$ specificity, 69.2\% PPV, 94.6\% NPV and a DA of $88 \%$ (Table 1). Closely related results were obtained by Gad et al., (2014) who found that Amsel's criteria had a sensitivity of $88 \%$ and a specificity of $89.6 \%$ for the diagnosis of $\mathrm{BV}$ compared to the Nugent score. However, higher sensitivity $(91 \%$ and $91 \%$ ) and specificity (99\% and $91 \%$ ) for Amsel's criteria were reported by Bradshaw et al., (2005) and Mohammadzadeh et al., (2015), respectively. On the other hand, in the studies of Beverly et al., (2005), Dadhwal et al., (2010), Modak et al., (2011), Khatoon et al., (2013) and Taj et al., (2014), a much lower sensitivity $(37 \%, 51.2 \%, 66.7 \%, 69 \%$, and $68.3 \%$ respectively) with a higher specificity $(99 \%, 98 \%, 94.7 \%, 93.1 \%$, and $97.1 \%$ respectively) were reported.

In accordance to the results of $\mathrm{Gad}$ et al., (2014), we observed a good agreement between the diagnosis of $\mathrm{BV}$ based on Amsel's criteria and the Nugent's scoring $($ Kappa $=0.672)$.

Comparison between the results of the BVBlue test and the results of Amsel's criteria

In the present work, there was a good agreement between the results of the BVBlue test and the clinical diagnosis by Amsel's criteria (kappa=0.716) (Table 2). However, the BVBlue test was more sensitive than the Amsel's criteria, $100 \%$ versus $81.8 \%$, when compared to the Nugent's score. Yet, the specificity of both methods was more or less the same (84.6\% versus $89.7 \%)$. This finding goes in agreement with Myziuk et al., (2003).

Diagnostic performance of vaginal swab culture compared to Nugent score $\geq 7$

Vaginal swabs yielded mixed growth in $72 \%$ of cultures (36/50). Anaerobic organisms were recovered from $40 \%$ (20/50) of vaginal swab cultures whereas Candida spp. was recovered from 34\% (17/50) and 36\% (18/50) of the cultures yielded growth of facultative anaerobic organisms.

As we compared the results of anaerobic culture to that of Nugent's score $\geq 7$, we found that the vaginal swab culture had $81.8 \%$ sensitivity, $71.8 \%$ specificity, $45 \%$ PPV, 93.3\% NPV and a DA of $74 \%$ (Table 1). Goyal et al., (2005) compared the isolation of anaerobes to the Nugent's score and reported that culture has $71.4 \%$ sensitivity, $84.7 \%$ 
specificity, 58.8\% PPV and 98.6\% NPV. Pavani and Saileela (2013) demonstrated that cultures had a low sensitivity and NPV (42.55\% and $84.4 \%$, respectively) with a high specificity and PPV (92.99\% and $64.51 \%$, respectively) in diagnosing BV. Finally, Gad et al., (2014) compared vaginal swab culture to Nugent's score $\geq 7$ and reported that culture had $90.9 \%$ sensitivity, $88 \%$ specificity, $79 \%$ PPV, and 95.2\% NPV.

In the present study, a statistically significant association was observed between the isolation of Prevotella spp. and BV $(\mathrm{P}<0.01)$ (Table 3). Prevotella spp. was the most commonly isolated organism from patients with BV (Nugent's score $\geq 7)(6 / 11 ; 54.5 \%)$ and none of the patients $(0 \%)$ with normal Nugen'ts score had Prevotella spp. isolated. Ling et al., (2013) indicated that vaginal pathogenic bacteria such as Gardenerella vaginalis, Prevotella spp., Atopium vaginae, Eggerthella and Leptotrichia/Sneathia are highly predictable for $\mathrm{BV}$, with excellent diagnostic accuracy. Unfortunately, in the present work, we failed to isolated Gardenerella vaginalis by the routine culture methods followed in our laboratories.

Among patients with normal Nugent's score, the predominant isolate was Candida spp. $(14 / 31,45 \%)$. There was a statistically significant difference between patients with Nugent's score $\geq 7$ and those with Nugent's score $<7$ regarding the isolation of Candida spp. $(\mathrm{P}<0.01)$ (Table 3). This finding recalls the previous report of Rodrigues et al., (1999) on the in-vitro, dose-dependent inhibitory effect of puterscine and cadaverine on germ tube formation by Candida albicans as well as on budding of strains of other Candida spp. The authors hypothesized that the presence of these and possibly other bacterial amines produced by anaerobes in the vaginal flora and seen in BV, may explain why candidiasis is rarely seen in these instances. Thus, finding a positive Candida spp. culture in the presence of BV may constitute a mixed vaginal infection but not mixed vaginitis, since positive vaginal cultures may reflect only Candida spp. colonization, a common finding in $10 \%-15 \%$ of healthy reproductive age women.

Table.1 The performance characteristics of the different studied methods compared to the Nugent's scoring

\begin{tabular}{|c|c|c|c|c|c|c|c|c|}
\hline & \multicolumn{3}{|c|}{ Nugent Score } & \multirow[b]{2}{*}{ Sensitivity } & \multirow[b]{2}{*}{ Specificity } & \multirow[b]{2}{*}{ PPV } & \multirow[b]{2}{*}{ NPV } & \multirow[b]{2}{*}{$\begin{array}{l}\text { Diagnostic } \\
\text { Accuracy }\end{array}$} \\
\hline & $\begin{array}{l}1-3 \\
(n= \\
31)\end{array}$ & $\begin{array}{c}4-6 \\
(n=8)\end{array}$ & $\begin{array}{l}\geq 7 \\
(\mathbf{n}= \\
\mathbf{1 1})\end{array}$ & & & & & \\
\hline $\begin{array}{l}\text { Amsel's } \\
\text { Criteria } \\
+\mathrm{ve}(\mathrm{n}=12)\end{array}$ & 1 & 3 & 9 & $81.8 \%$ & $89.7 \%$ & $69.2 \%$ & $94.6 \%$ & $88 \%$ \\
\hline $\begin{array}{l}\text { BVBlue } \\
+ \text { ve }(n=17)\end{array}$ & 3 & 3 & 11 & $100 \%$ & $84.6 \%$ & $64.7 \%$ & $100 \%$ & $88 \%$ \\
\hline $\begin{array}{l}\text { Culture } \\
\text { growing } \\
\text { anaerobic } \\
\text { organism } \\
(\mathrm{n}=20)\end{array}$ & 5 & 6 & 9 & $81.8 \%$ & $71.8 \%$ & $45 \%$ & $93.3 \%$ & $74 \%$ \\
\hline
\end{tabular}


Table.2 Agreement between the results of the BVBlue test and those of Nugent's score and Amsel's criteria

\begin{tabular}{|c|c|c|c|c|}
\hline & \multicolumn{2}{|c|}{ BVBlue Test } & \multirow{2}{*}{ Kappa coefficient } \\
\hline & & Positive & Negative & \\
\hline \multirow[t]{2}{*}{ Nugent Score } & Score $\geq 7$ & 11 & 0 & \multirow{2}{*}{0.708} \\
\hline & Score $<7$ & 6 & 33 & \\
\hline & & \multicolumn{2}{|c|}{ BVBlue Test } & \multirow{2}{*}{ Kappa coefficien } \\
\hline & & Positive & Negative & \\
\hline \multirow[t]{2}{*}{ Amsel's criteria } & $\geq 3(+$ ve BV $)$ & 12 & 1 & \multirow{2}{*}{0.716} \\
\hline & $<3(-$ ve BV $)$ & 5 & 32 & \\
\hline
\end{tabular}

Table.3 Association between BV (Nugent's score $\geq 7$ ) and the most commonly isolated organisms

\begin{tabular}{|c|c|c|c|c|}
\hline & & \multicolumn{2}{|c|}{ Nugent's score } & \multirow{2}{*}{ Significance } \\
\hline & & Score $\geq 7$ & Score $<7$ & \\
\hline \multirow{2}{*}{ Prevotella spp } & Positive & 6 & 3 & \multirow{2}{*}{$\begin{array}{c}0.002 * \\
(\mathrm{HS})\end{array}$} \\
\hline & Negative & 5 & 36 & \\
\hline & & \multicolumn{2}{|c|}{ Nugent's score } & \multirow{2}{*}{ Significance } \\
\hline & & Score $\geq 7$ & Score $<7$ & \\
\hline \multirow{2}{*}{ Bacteroids spp } & Positive & 3 & 9 & \multirow{2}{*}{$\begin{array}{c}1.000^{*} \\
(\mathrm{NS})\end{array}$} \\
\hline & Negative & 8 & 30 & \\
\hline & & \multicolumn{2}{|c|}{ Nugent's score } & \multirow{2}{*}{ Significance } \\
\hline & & Score $\geq 7$ & Score $<7$ & \\
\hline \multirow{2}{*}{ Candida spp } & Positive & 0 & 17 & \multirow{2}{*}{$\begin{array}{c}0.009 * \\
(\mathrm{HS})\end{array}$} \\
\hline & Negative & 11 & 22 & \\
\hline
\end{tabular}

*Fisher's Exact Test; HS= highly significant, NS=non-significant

Table.4 Comparison between BVBlue positive and BVBlue negative patients regarding the most commonly isolated organisms

\begin{tabular}{|c|c|c|c|c|}
\hline & & \multicolumn{2}{|c|}{ BVBlue } & \multirow{2}{*}{$\begin{array}{c}P \text { value } \\
\text { (Significance) }\end{array}$} \\
\hline & & Positive & Negative & \\
\hline \multirow{2}{*}{ Prevotella spp } & Positive & 8 & 1 & \multirow{2}{*}{$\begin{array}{l}0.00^{\mathrm{a}} \\
(\mathrm{HS})\end{array}$} \\
\hline & Negative & 9 & 32 & \\
\hline & & \multicolumn{2}{|c|}{ BVBlue } & \multirow{2}{*}{ Significance } \\
\hline & & Positive & Negative & \\
\hline \multirow{2}{*}{ Bacteroids spp } & Positive & 8 & 4 & \multirow{2}{*}{$\begin{array}{l}0.01^{\mathrm{a}} \\
(\mathrm{S})\end{array}$} \\
\hline & Negative & 9 & 29 & \\
\hline & & \multicolumn{2}{|c|}{ BVBlue } & \multirow{2}{*}{ Significance } \\
\hline & & Positive & Negative & \\
\hline \multirow{2}{*}{ Candida spp } & Positive & 5 & 12 & \multirow{2}{*}{$\begin{array}{l}0.62^{\mathrm{b}} \\
(\mathrm{NS})\end{array}$} \\
\hline & Negative & 12 & 21 & \\
\hline
\end{tabular}

${ }^{\mathrm{a}}$ Fisher's Exact Test; ${ }^{\mathrm{b}} \mathrm{Chi}$ square test, $\mathrm{HS}=$ highly significant, NS=non-significant, $\mathrm{S}=$ significant 
Association between results of BVBlue test and culture results

A statistically significant difference was observed between BVBlue positive and BVBlue negative patients regarding the isolation of Prevotella spp. $(\mathrm{P}<0.01)$ and Bacteroides spp. $\quad(\mathrm{P}<0.05) \quad($ Table 4). Similarly, Briselden et al., (1992) reported that $96 \%$ of women with $\mathrm{BV}$ and positive sialidase activity had sialidase-positive bacteria recovered from vaginal fluid. The authors found that Prevotella spp. and Bacteroides spp. are the probable sources of sialidase in patients with BV. They could not correlate the presence of Gardnerella vaginalis, Mobiluncus spp., Peptostreptococcus spp., or Mycoplasma hominis with increased sialidase activities of greater than $7 \mathrm{U}$. By contrast, McGregor et al., (1994) correlated the sialidase activity, in women with BV, with the isolation of Gardenerella vaginalis, Mobiluncus spp., Mycoplasma hominis, Chlamydia trachomatis, and yeast. They did not specifically identify Prevotella spp. or other anaerobic bacteria associated with BV.

In the current work, no significant difference was observed between BVBlue positive and BVBlue negative women regarding the isolation of Candida spp. (P>0.05) (Table 4). Similar finding was observed by Myziuk et al., (2003).

We concluded that detection of sialidase activity can be beneficial for the diagnosis of $\mathrm{BV}$ in the clinic setting where microscopic capabilities are not available. The BVBlue test proved to be a simple, objective and sensitive point of care test that can be used for the rapid diagnosis of BV at physician's office. Results are available in 10 minutes, thus the patients would benefit in terms of immediate diagnosis and treatment in the same setting instead of evaluating Gram stained smears (Nugent's method) which requires a skilled manpower, laboratory facilities and is prone to subjective errors.

\section{References}

Akhter, S., Satter, H., Tarafder, S., Miah, R., Shamin, S., and Ahmed, S. 2010. Rapid Detection of Bacterial Vaginosis (BV) by BVBlue test, Bangladesh. J. Med. Microbiol., 4(1): 24-27.

Allsworth, J.E., and Peipert, J.F. 2011. Severity of bacterial vaginosis and the risk of sexually transmitted infection. The American J. Obstetrics Gynecol., 205(2): 113.

Beverly, E.S., Chen, H.Y., Wang, Q.J., Zariffard, M.R., Cohen, M.H., and Spear, G.T. 2005. Utility of Amsel criteria, Nugent score, and quantitative PCR for Gardnerella vaginalis, Mycoplasma hominis, and Lactobacillus spp. for diagnosis of bacterial vaginosis in human immunodeficiency virus-infected women. J. Clin. Microbiol., 43(9): 4607-4612.

Bhalla, P., Chawla, R., Garg, S., Singh, M.M., Raina, U., Bhalla, R., and Sodhanit, P. 2007. Prevalence of bacterial vaginosis among women in Delhi, India. Indian J. Med. Res., 125(2):167-72.

Bradshaw, C.S., Morton, A.N., Garland, S.M., Horvath, L.B., Kuzevska, I., and Fairley. C.K. 2005. Evaluation of a point-of-care test, BVBlue, and clinical and laboratory criteria for diagnosis of bacterial vaginosis. J. Clin. Microbiol., 43: 13048.

Briselden, A.M., Moncla, B.J., Stevens, C.E., and Hillier, S.L. 1992. Sialidases (neuraminidases) in bacterial vaginosis and bacterial vaginosis associated microflora. J. Clin. Microbiol., 30: 663666.

Calderon, C., Rivera, R., Gordillo, S. and Conde-Glez, C. 1997. Evaluation of a fast test to identify the presence of proline aminopeptidase in women with bacterial vaginosis. Infect. Dis. Obstetrics and 
Gynecol., 5(3): 226-231.

Cauci, S., Hitti, J., Noonan, C., Agnew, K., Quadrifoglio, F., Hillier, S.L., and Eschenbach, D.A. 2002. Vaginal hydrolytic enzymes, immunoglobulin A against Gardnerella vaginalis toxin, and risk of early preterm birth among women in preterm labor with bacterial vaginosis or intermediate flora. Am. J. Obstet. Gynecol., 187: 877-881.

Cauci, S., Driussi, S., Monte, R., Lanzafame, P., Pitzus, E., and Quadrifoglio, F. 1998. Immunoglobulin A response against Gardnerella vaginalis hemolysin and sialidase activity in bacterial vaginosis. The American J. Obstetrics and Gynecol., 178(3): 511-515.

Dadhwal, V., Hariprasad, R., Mittal, S., and Kapil, A. 2010. Prevalence of bacterial vaginosis in pregnant women and predictive value of clinical diagnosis. Arch. Gynecol. Obstet., 281: 101-104.

Darwish, A.M., Makarem, M.H., Al-Nashar, E.M. and Hamadeh, S.M. 2005. Screening for bacterial vaginosis in highrisk pregnancy: the experience of a developing country. Acta Obstet. Gynecol. Scand., 84: 483-485.

Das, T.R., Jahan, S., Begum, S.R., and Akhtar, M.F. 2011. Association between bacterial vaginosis and pretermdelivery. Mymensingh Med. J., 20(1): 115-120.

Desseauve, D., Chantrel, J., Fruchart, A., Khoshnood, B., Brabant, G., Ancel, P.Y., and Subtil, D. 2012. Prevalence and risk factors of bacterial vaginosis during the first trimester of pregnancy in a large French population-based study. Eur. J. Obstet. Gynaecol. Reprod. Biol., 163(1): 30-4.

Di Vico, A., Donati, L., Labianca, A., and Paradisi G. 2011. Role of vaginal infection in fetal and neonatal mortality. Minerva Ginecologica, 63(1): 25-30.

Fredricks, D.N., Fiedler, T.L., and Marrazzo, J.M. 2005. Molecular identification of bacteria associated with bacterial vaginosis. N. Engl. J. Med., 353: 18991911.
Gad, G.M., El-Adawy, A.R., Mohammed, M.S., Ahmed, A.F., and Heba, A.M. 2014. Evaluation of different diagnostic methods of bacterial vaginosis. IOSR $J$. Dent. Med. Sci., 13(1): 15-23.

Goyal, R., Sharma, P., Kour, I., Aggarwal, N., and Talwar, V. 2005. Diagnosis of bacterial vaginosis in women in labour. JK Sci., 7(1).

Haggerty, C.L., Hillier, S.L., Bass, D.C., and Ness, R.B. 2004. Bacterial vaginosis and anaerobic bacteria are associated with endometritis. Clin. Infect. Dis., 39: 990995.

Haltas, H., Bayrak, R. and Yenidunya, S. 2012. To determine the prevalence of bacterial vaginosis, Candida spp., mixed infections (bacterial vaginosis + Candida sp), Trichomonas vaginalis, Actinomyces sp in Turkish women from Ankara, Turkey. Ginekol. Pol., 83(10): 744-8.

Hilbert, D.W., Smith, W.L., Chadwick, S.G., Toner, G., Mordechai, E., Adelson, M.E., Aguin, T.J., Sobel, J.D. and Gygax, S.E. 2016. Development and validation of a highly accurate quantitative Real-Time PCR assay for diagnosis of bacterial vaginosis. J. Clin. Microbiol., 54(4): 1017-1024.

Howe, L., Wiggins, R., Soothill, P.W., Millar, M.R., Horner, P.J., and Corfield, A.P. 1999. Mucinase and sialidase activity of the vaginal microflora: implications for the pathogenesis of preterm labour. Int. J. STD AIDS, 10: 442-447.

Jayakrishnan, C., Rajalekshmi, M., Nithya, R., and Vijay Narayanan, S. 2016. Role of bacterial vaginosis in threatened preterm and preterm labour, and its screening Chithra. Indian J. Obstetrics and Gynecol. Res., 3(2): 115-120.

Jones, F.R., Miller, G., Gadea, N., Meza, R., Leon, S., Perez, J., Lescano, A.G., Pajuelo, J., Caceres, C.F., Klausner, J.D., and Coates, T.J. 2007. Prevalence of bacterial vaginosis among young women in low-income populations of coastal Peru. Int. J. STD AIDS, 18: 188-192. 
Kampan, N.C., Suffian, S.S., Ithnin, N.S., Muhammad, M., Zakaria, S.Z., and Jamil, M.A. 2011. Evaluation of BVBlue test kit for the diagnosis of bacterial vaginosis. Sexual and Reproductive Healthcare, 2(1): 1-5.

Khatoon, R., Jahan, N., Ahmad, S. and Rabbani, T. 2013. Comparison of OSOM BVBlue test with conventional methods for diagnosis of bacterial vaginosis. African. J. Microb. Res., 7(28): 3698-3703.

Landers, D.V., Wiesenfeld, H.C., Heine, R.P., Krohn, M.A., and Hillier, S.L. 2004. Predictive value of the clinical diagnosis of lower genital tract infection in women. Am. J. Obstet. Gynecol., 190: 1004-1010.

Ling, Z., Liu, X., Luo, Y., Wu, X., Yuan, L., Tong, X., Li, L., Xiang, C. 2013. Associations between vaginal pathogenic community and bacterial vaginosis in Chienese reproductive-age women. PLoS One, 8(10): e76589.

Livengood, C.H. 2009. Bacterial vaginosis: an overview for 2009. Rev. Obstet. Gynecol., 2: 28-37.

Madhivanan, P., Krupp, K., Chandrasekaran, V., Karat, C., Arun, A., Cohen, C.R., Reingold, A.L., and Klausner, J.D. 2008. Prevalence and correlates of bacterial vaginosis among young women of reproductive age in Mysore, India. Indian J. Med. Microbiol., 26(2): 132-137.

Martin, H.L., Richardson, B.A., Nyange, P.M., Lavreys, L., Hillier, S.L., Chohan, B., Mandaliya, K., Ndinya-Achola, J.O., Bwayo, J., and Kreiss, J. 1999. Vaginal Lactobacilli, microbial flora, and risk of human immunodeficiency virus type 1 and sexually transmitted disease acquisition. J. Infect. Dis., 180: 1863-8.

McGregor, J.A., French, J.I., Jones, W., Milligan, K., McKinney, P.J., Patterson, E., and Parker, R. 1994. Bacterial vaginosis is associated with prematurity and vaginal fluid mucinase and sialidase: results of a controlled trial of topical clindamycin cream. Am. J. Obstet. Gynecol., 170: 1048-1060.
Mengistie, Z., Woldeamanuel, Y., Asrat, D., and Yigeremu, M. 2013. Comparison of clinical and Gram stain diagnosis methods of bacterial vaginosis among pregnant women in Ethiopia. J. Clin. Diagnostic Res., 7(12): 2701-2703.

Modak, T., Arora, P., Agnes, C., Ray, R., Goswami, S., Ghosh, P., and Das, N.K. 2011. Diagnosis of bacterial vaginosis in cases of abnormal vaginal discharge: comparison of clinical and microbiological criteria. J. Infect. Dev. Ctries., 5(5): 353-60.

Mohammadzadeh, F., Dolatian, M., Jorjani, M. and Majd, H.A. 2015. Diagnostic value of Amsel's clinical criteria for diagnosis of bacterial vaginosis. Global J. Health Sci., 7(3): $8-14$

Money, D. 2005. The laboratory diagnosis of bacterial vaginosis. Can. J. Infect. Dis. Med. Microbiol., 16(2): 77-79.

Myziuk, L., Romanowski, B., and Johnson, S. 2003. BVBlue test for diagnosis of bacterial vaginosis. J. Clin. Microbiol., 41(5): 1925-1928.

Nelofer, S., Habiba, S.A., and Rubina, H. 2006. Prevalence of bacterial vaginosis in pregnant women and efficacy of rapid diagnostic tests in its diagnosis. Infect. Dis. J. Pak., 93-95.

Nugent, R.P., Krohn, M.A., and Hillier, S.L. 1991. Reliability of diagnosing bacterial vaginosis is improved by a standardized method of Gram stain interpretation, $J$. Clin. Microbiol., 29: 297-301.

Olmsted, S.S., Meyn, L.A., Rohan, L.C., and Hillier, S.L. 2003. Glycosidase and proteinase activity of anaerobic Gramnegative bacteria isolated from women with bacterial vaginosis. Sex. Transm. Dis., 30: 257-261.

Pavani, K., and Saileela, K. 2013. Diagnosis of bacterial vaginosis in reproductive age group in tertiary health care hospital in south India: Comparison of clinical and microbiological criteria. J. Evolut. Med. Dent. Sci., 2(35): 6611-6615.

Randis, T.M., Kulkarni, R., Aguilar, J.L., and Ratner, A.J. 2009. Antibody-based 
detection and inhibition of vaginolysin, the Gardenerella vaginalis cytolysin. PLOS ONE, 4(4): e5207.

Rodrigues, A.G., Mardh, P-A., Pina-Vaz, C., de-Oliveira, J.M., and da Fonseca, A.F. 1999. Is the lack of concurrence of bacterial vaginosis and vaginal candidosis explained by the presence of bacterial amines? Am. J. Obstet. Gyn., 181(2): 367370.

Rubins, A. 2011. Bacterial Vaginosis. In: Gross, G., Tyring, S.K, editors. Transmitted Infections and Sexually Transmitted Diseases Sexually. Berlin: Springer. p. 203-6.

Taj, N., Shams Ul Alam, M., Sarah, Bajway, Z., Abdul Waheed, and Ehsan Ullah (2014. Bacterial Vaginosis in Pregnant Women and its diagnosis using Amsel's clinical criteria and Nugent's method. $P J M H S$, 8(1): 133-135.

Tanuja, C., Disha, P., and Praveg, G. 2008. Diagnosis and prevalence of bacterial vaginosis in a rural and urban setup of Surat. J. Obstet. Gynecol. India, 58(5): 402-405.
Taylor, B.D., Darville, T., and Haggerty, C.L. 2013. Does bacterial vaginosis cause pelvic inflammatory disease? Sex. Transm. Dis., 40:117-22.

West, B.L., Morison, L., Schim van der Loeff, M.,,Gooding, E., Awasana, A.A., Demba, E., and Mayaud, P. 2003. Evaluation of a new rapid diagnostic kit (FemExam) for bacterial vaginosis in patients with vaginal discharge syndrome in The Gambia. Sex. Transm. Dis., 30: 483-489.

Wiggins, R., Crowley, T., Horner, P.J., Soothill, P.W., Millar, M.R., and Corfield, A.P. 2000. Use of 5-bromo-4-chloro-3-indolylalpha-D-Nacetylneuraminic acid in a novel spot test to identify sialidase activity in vaginal swabs from women with bacterial vaginosis. J. Clin. Microbiol., 38: 3096-7.

Wiggins, R., Hicks, S.J., Soothill, P.W., Millar, M.R. and Corfield, A.P. 2001. Mucinases and sialidases: their role in the pathogenesis of sexually transmitted infections in the female genital tract. Sex. Transm. Infect., 77: 402-408.

\section{How to cite this article:}

Fatma AL-Zahraa M. Gomaa, Hala M. Hafez, Ahmed Al Anwar, Noureen I. El-Metwally. 2017. Diagnosis of Bacterial Vaginosis among Symptomatic Egyptian Women: Value of Assessing Bacterial Sialidase Activity. Int.J.Curr.Microbiol.App.Sci. 6(4): 906-917.

doi: https://doi.org/10.20546/ijcmas.2017.604.115 